\title{
Controlling weapons circulation in a postcolonial militarised world
}

\author{
Anna Stavrianakis* \\ Department of International Relations, University of Sussex \\ *Corresponding author. Email: A.Stavrianakis@sussex.ac.uk
}

(Received 25 July 2017; revised 16 May 2018; accepted 21 May 2018; first published online 25 July 2018)

\begin{abstract}
What are the politics of, and prospects for, contemporary weapons control? Human rights and humanitarian activists and scholars celebrate the gains made in the UN Arms Trade Treaty as a step towards greater human security. Critics counter that the treaty represents an accommodation with global militarism. Taking the tensions between arms transfer control and militarism as my starting point, I argue that the negotiating process and eventual treaty text demonstrate competing modes of militarism. Expressed in terms of sovereignty, political economy, or human security, all three modes are underpinned by ongoing imperial relations: racial, gendered, and classed relations of asymmetry and hierarchy that persist despite formal sovereign equality. This means human security is a form of militarism rather than the antithesis of it. Drawing on primary sources from negotiations and participant observation with actors involved in the campaign for the ATT, the argument challenges the idea that human security has scored a victory over militarism. It also complicates our understanding of the nature of the accommodation with it, demonstrating the transformation as well as entrenchment of contemporary militarism. The argument reframes the challenges for controlling weapons circulation, placing the necessity for feminist, postcolonial anti-militarist critique front and centre.
\end{abstract}

Keywords: Arms Control; Arms Trade; Gender; Human Security; Imperial Relations; Militarism

\section{Introduction}

At a time when the misuse of weapons is increasingly visible in human rights violations, breaches of international humanitarian law (IHL), terrorism, war and armed violence around the world, the 2013 Arms Trade Treaty (ATT) provides, for many, a glimmer of hope. The ATT represents the apogee of over two decades of diplomacy, advocacy, and campaigning by a North-South coalition of small and medium-sized states and non-governmental organisations (NGOs). The treaty has been widely celebrated as a step forward in humanitarian arms control and a victory for human security, given its goal of reducing human suffering, and the inclusion of IHL and human rights standards in its provisions. Scholar and practitioner proponents hope that the treaty will 'diminish the human cost of the poorly regulated arms trade', with the effect of 'humanizing international security'. Since its entry into force in December 2014 though, the signs have not been encouraging. Controversy over exports by the UK, an ATT State Party, to Saudi Arabia and its coalition partners for use in the war in Yemen, as well as the challenges of

\footnotetext{
${ }^{1}$ Daniel Mack, 'The Arms Trade Treaty PrepCom: Prepared and committed?', Arms Control Today, 40 (July/ August 2010).

${ }^{2}$ Denise Garcia, 'Humanitarian security regimes', International Affairs, 91:1 (2015), pp. 55-75.
} 
engaging states not party to the treaty there and in cases such as the war in Syria, are just the most politically prominent cases (in Western debates, at least) of the human cost of war and of the challenges facing the ATT.

This article inquires into the significance of the ATT for controlling weapons circulation. Most of the emerging academic literature on the treaty situates it as part of the post-Cold War trend of humanitarian arms control, prioritising human security over state security, or at least making them complementary. Such accounts draw on and extend disarmament efforts to ban specific weapons technologies (landmines, cluster munitions, and nuclear weapons) and control efforts to regulate others (small arms and light weapons (SALW)). Critics, meanwhile, argue that the ATT represents an accommodation with global or liberal militarism. In this article I take the tensions between arms transfer control and militarism as my starting point, arguing that the negotiating process and eventual text of the ATT demonstrate the competing modes of militarism in play in the contemporary, postcolonial world. These different modes of militarism are expressed in terms of sovereignty, political economy, or human security, and are all underpinned by ongoing imperial relations: racial, gendered, and classed relations of asymmetry and hierarchy that persist despite formal sovereign equality in the UN system in which arms trade regulation is negotiated. This means seeing human security as a form of militarism rather than the antithesis of it: circumscribed by liberal conceptions of human rights and IHL, but with little to say about intra-Western arms transfers, global military spending, or the entrenchment of military interests in societies and economies around the world, and with little political force to counter allegations of hypocrisy due to controversial transfers or double standards. Such an argument challenges the idea that the human security agenda has been a victory over militarism, and complicates our understanding of the nature of the accommodation with it, demonstrating the transformation as well as entrenchment of contemporary militarism. The argument also reframes the challenge facing weapons control, placing the necessity for feminist, postcolonial antimilitarist critique front and centre.

The argument unfolds in three steps. First, I outline the debate between proponents of humanitarian arms control and human security, and critics who focus on militarism. Second, I trace the transformation of human security over time in relation to weapons issues, arguing that the scholarship on the arms trade and on human security needs to both foreground feminist critiques of militarism and postcolonial critiques of international politics, to counter the dominant trends of optimism and presentism, and benevolent and linear accounts of history. Third, I outline three competing modes of militarism expressed in terms of sovereignty, political economy and human security, and illustrate their contestation through three controversies and one silence that structured the ATT negotiations and eventual text. The controversies relate to the definition of the illicit trade; the treatment of human rights and IHL; and diversion and the treatment of ammunition. The silence is around domestic procurement and civilian possession, both of which are excluded from the international regulatory agenda. The research is based on close reading of primary sources from states, organisations, research institutes, and NGOs involved in the campaign, ${ }^{3}$ combined with participant observation work with pro-control $\mathrm{NGOs}^{4}$ and at ATT negotiation, implementation and training events.

\footnotetext{
${ }^{3}$ See, for example $\{$ http://armstreaty.org/\}; Arms Trade Treaty Legal blog, available at: $\{$ http://armstradetreaty.blogspot.co. uk/\}; ATT Monitor blog, available at: \{http://attmonitor.blogspot.co.uk/\}; Reaching Critical Will, available at: \{http:// reachingcriticalwill.org/disarmament-fora/att\}.

${ }^{4}$ The Control Arms coalition led the civil society campaign for the ATT. Their activism was contested by the US National Rifle Association (NRA) and World Forum on the Future of Sport Shooting Activities (WFSA). On pro-gun civil society activism, see Clifford Bob, The Global Right Wing and the Clash of World Politics (Cambridge: Cambridge University Press, 2012).
} 


\section{Humanitarian arms control, human security, and their critics}

Adopted by a majority vote at the United Nations General Assembly in April 2013 (154 in favour, 3 against, 23 abstentions), the ATT entered into force on 24 December 2014 once 50 states had ratified it. There are 130 signatories to the treaty, of which 94 are States Parties at the time of writing. It aims to '[e]stablish the highest possible common international standards for regulating or improving the regulation of the international trade in conventional arms' and '[p]revent and eradicate the illicit trade in conventional arms and prevent their diversion.' this, the treaty text sets out the core provisions that States Parties must implement in their national regulatory systems governing the transfer - import, export, transit, trans-shipment, or brokering - of weapons ranging from battle tanks and combat aircraft, to SALW. A set of prohibitions based on existing international law stipulate that States Parties must not authorise transfers if doing so would violate UN Security Council arms embargoes or be used in genocide or other war crimes. If a transfer is not prohibited in this way, States Parties must conduct a risk assessment against a series of factors, including human rights, IHL, terrorism and transnational organised crime, to decide whether or not to authorise exports.

The ATT is in many ways the epitome of post-Cold War humanitarian arms control and the broader human security agenda. The purpose of reducing human suffering, the inclusion of IHL and human rights in the operative provisions of the treaty and of SALW in the scope of weapons to be regulated, as well as the landmark inclusion of gender-based violence (GBV) as an issue States Parties must take account of when approving weapons exports, all point to the ways in which human security and humanitarian arms control attempt to protect individuals in war and in situations of armed violence. Key features of the negotiating process - the role of small and middle powers, and civil society; and the challenges posed to the sclerotic UN negotiating machinery - resonate with the global governance elements of previous human security-related weapons campaigns against landmines, cluster munitions, and SALW. ${ }^{6}$ Indeed, Jennifer Erickson describes the process as a 'marriage between traditional security and human security begun by the landmine campaign'.

Activists and scholars have attempted to elevate human rights and humanitarian concerns for the broad swath of the world's population above the political economy and security interests of states and arms-producing companies. Weapons-specific initiatives such as the 1997 Mine Ban Treaty and 2008 Convention on Cluster Munitions had shown the impact that a humanitarian framing can have in relation to particular technologies. The negotiation of the 2001 Programme of Action to Prevent, Combat and Eradicate the Illicit Trade in Small Arms and Light Weapons in All Its Aspects showed the challenge of applying human security principles to weapons with legitimate military and security uses - a challenge that was to resurface during the ATT negotiations. Regulating the conventional arms trade as a whole cannot take a purely disarmament or humanitarian frame, given its deeply entrenched legitimacy. This makes the ATT a human security initiative rather than a primarily humanitarian arms control or disarmament one ${ }^{8}-$ while

\footnotetext{
${ }^{5}$ United Nations, The Arms Trade Treaty, Article 1 (2013), available at: \{https://unoda-web.s3.amazonaws.com/wp-content/uploads/2013/06/English7.pdf\}.

${ }^{6}$ See, for example, John Borrie, 'The "Long Year": Emerging international efforts to address the humanitarian impacts of cluster munitions, 2006-2007’, Yearbook of International Humanitarian Law, 10 (2007), pp. 251-75; Maxwell A. Cameron, Robert J. Lawson, and Brian W. Tomlin, To Walk Without Fear: The Global Movement to Ban Landmines (Oxford: Oxford University Press, 1998); Keith Krause, 'Multilateral diplomacy, norm building, and UN conferences: the case of small arms and light weapons', Global Governance, 8 (2002), pp. 247-63.

${ }^{7}$ Jennifer Erickson, Dangerous Trade: Arms Exports, Human Rights, and International Reputation (New York: Columbia University Press, 2015), p. 62.

${ }^{8} \mathrm{An}$ absolute ban, requirement for remedial measures, and cooperative approach to implementation are what mark out humanitarian disarmament initiatives from other control measures. Bonnie Docherty, 'Ending civilian suffering: the purpose, provisions, and promise of humanitarian disarmament law', Austrian Review of International and European Law, 15 (2010), pp. 7-8.
} 
it has the reduction of human suffering as a named purpose, this sits alongside international and regional peace, security and stability' in Article 1 of the text. As Mary Martin and Taylor Owen put it, 'The idea of arms control is appealing to proponents of human security because it sets out to control tools of violence, as well as seeking to curb the dominance of the state in determining the forms of insecurity to which policy solutions must be found.' ${ }^{, 9}$ Jody Williams, founding coordinator of the ICBL, calls on governments and civil society to work together, including on initiatives like the ATT, 'to advance human security as a viable alternative to militarism and violence and war'. ${ }^{10}$

Sympathetic criticism of the ATT has been aired from within the academic and scholarpractitioner community. Matthew Bolton and Katelyn E. James argue that the treaty represents a 'melding' of a "'maximalist" human security - civil society approach with concerns of developing countries and the "minimalist" strategic and commercial interests of the major arms exporters. ${ }^{11}$ Christine Chinkin and Mary Kaldor argue that 'the humanitarian achievements' of post-Cold War weapons control 'need to be complemented by disarmament'. That is, as well as 'bringing states' human rights obligations into the heart of weapons control', human security requires 'the reduction of existing weapon stocks and prohibition of the development, production and stockpiling of further weapons'. ${ }^{12}$ Such a call echoes the demand of the Women's International League for Peace and Freedom (WILPF), one of the civil society organisations active on the ATT, for disarmament as a longstanding, yet marginalised feminist concern. ${ }^{13}$

Others have been less sympathetically critical. For Neil Cooper, initiatives like the ATT 'do not represent a novel post-Cold War development that symbolizes progress on an emancipatory human security agenda'. ${ }^{14}$ Post-Cold War arms trade regulation has been based on a 'discourse around humanitarianism, human security and weapons precision' that has served to legitimise high-tech military technologies. ${ }^{15}$ Cooper and others emphasise the deep historical roots of the way humanitarian impulses intersect with economic and security ones, including in late nineteenth-century efforts to regulate the supply and circulation of weapons in the imperial peripheries that are remarkably resonant with contemporary efforts. ${ }^{16}$ Historically minded scholars remind us that surplus and obsolete weapons have long circulated in the peripheries of empire, and new weapons tested there; and political authorities were licensing weapons exports as early as the sixteenth century - in part to avoid blowback. ${ }^{17}$ Arms trade regulation, then, has a

\footnotetext{
${ }^{9}$ Mary Martin and Taylor Owens, 'Introduction', in Mary Martin and Taylor Owen (eds), Routledge Handbook of Human Security (London: Routledge, 2014), p. 9. For an example of this view, see Deepayan Basu Ray, 'Navigating the "national security" barrier: a human security agenda for arms control in the twenty-first century', in Martin and Owen (eds), Routledge Handbook of Human Security, pp. 197-209.

${ }^{10}$ Jody Williams, 'New approaches in a changing world: the human security agenda', in Jody Williams, Stephen D. Goose, and Mary Wareham (eds), Banning Landmines: Disarmament, Citizen Diplomacy, and Human Security (Lanham, MA: Rowman and Littlefield, 2008), p. 294.

${ }^{11}$ Matthew Bolton and Katelyn E. James, 'Nascent spirit of New York or ghost of arms control past? The normative implications of the Arms Trade Treaty for global policymaking', Global Policy, 5:4 (2014), p. 2.

${ }^{12}$ Christine Chinkin and Mary Kaldor, International Law and New Wars (Cambridge: Cambridge University Press, 2017), ch. 7.

${ }^{13}$ WILPF, WILPF Manifesto (2015), available at: $\{$ https://wilpf.org/wilpf_publications/wilpf-2015-manifesto/\}; J. Ann Tickner and Jacqui True, 'A century of international relations feminism: From World War I women's peace pragmatism to the Women, Peace and Security Agenda', International Studies Quarterly (2018), pp. 1-13.

${ }^{14}$ Neil Cooper, 'Humanitarian arms control and processes of securitization: Moving weapons along the security continuum', Contemporary Security Policy, 32:1 (2011), pp. 134-58; and Neil Cooper, 'Race, sovereignty and free trade: Arms trade regulation and humanitarian arms control in the age of empire', Journal of Global Security Studies (forthcoming, 2018).

${ }^{15}$ Cooper, 'Humanitarian arms control and processes of securitization'; Cooper, 'Race, sovereignty and free trade'.

${ }^{16}$ Mark Bromley, Neil Cooper, and Paul Holtom, 'The UN Arms Trade Treaty: Arms export controls, the human security agenda and the lessons of history', International Affairs, 88:5 (2012), p. 1031; David R. Stone, 'Imperialism and sovereignty: the League of Nations' drive to control the global arms trade', Journal of Contemporary History, 35:2 (2000), pp. 213-30.

${ }^{17}$ Emrys Chew, Arming the Periphery: The Arms Trade in the Indian Ocean during the Age of Global Empire (Basingstoke: Palgrave, 2012); Lina Grip, 'History never repeats? Imports, impact and control of small arms in Africa', Contemporary Security Policy, 36:1 (2015), pp. 79-103.
} 
'historically contingent' character, marked by the ongoing importance of 'power, interest, economy, security. ${ }^{18}$

Militarism emerges as a core concern out of such critiques and provides the jumping-off point for this analysis. In particular, there are long traditions of historical sociological and feminist scholarship on militarism, ${ }^{19}$ defined here as 'the social and international relations of the preparation for, and conduct of, organized political violence'. ${ }^{20}$ In relation to arms control, I have argued elsewhere that the ATT has been mobilised by liberal democratic states primarily to legitimise their arms transfer practices. ${ }^{21}$ And Cooper concludes that 'campaigners need to return to a strategic contestation of global militarism rather than searching for tactical campaign victories dependent on accommodation with the language and economic and security paradigms of contemporary military humanism'. ${ }^{22}$ This is part of a political economy critique of the way 'the regulation of pariah weapons might alternatively be described as "arms control from below within the logic of militarism from above", ${ }^{23}$ in line with a wider critique of human security as having been institutionalised and co-opted to work in the interests of global capitalism, militarism and neoliberal governance. ${ }^{24}$ Neil Cooper and David Mutimer, surveying the history of and prospects for controlling the means of violence, argue that 'the longer term, indirect effect should be to reduce militarism and promote cultures of peace' or 'at the very least, avoid further embedding cultures of militarism'. ${ }^{25}$ How, then, should we think about the impact of the human security agenda on militarism, and vice versa; and what are the ramifications for weapons control?

\section{From militarism to human security - and back via the imperial turn}

The 1994 UNDP Human Development Report, which formalised the human security agenda, was explicit about the role of 'excessive militarization and the international arms trade' as a 'critical source of insecurity'. ${ }^{26}$ Arising from 'the world's previous preoccupation with deterrence and territorial security', arms transfers, military assistance, proxy wars, excessive military spending, politicised militaries in developing countries, and the military-industrial complex, were all identified as impediments to the realisation of human security. ${ }^{27}$ The report identified concrete policy recommendations, including an international agreement to phase out military assistance; a list of prohibited items for transfer; a strengthened UN Register reporting system; the regulation and elimination of subsidies; and a tax on arms sales to finance peacekeeping. ${ }^{28}$ Such moves, alongside increased spending on demilitarisation efforts, were envisaged as 'an

\footnotetext{
${ }^{18}$ Cooper, 'Humanitarian arms control and processes of securitization', p. 154.

${ }^{19} \mathrm{See}$, for example, Cynthia Cockburn, 'Gender relations as causal in militarization and war', International Feminist Journal of Politics, 12:2 (2010); Cynthia Enloe, Does Khaki Become You? The Militarization of Women's Lives (London: Pandora Press, 1988); Michael Mann, 'The roots and contradictions of modern militarism', New Left Review, I:162 (1987), pp. 35-50; Martin Shaw, Post-Military Society: Militarism, Demilitarization and War at the End of the Twentieth Century (Cambridge: Policy Press, 1991); Laura Sjoberg and Sandra Via (eds), Gender, War and Militarism: Feminist Perspectives (Santa Barbara: Praeger, 2010).

${ }^{20}$ Anna Stavrianakis and Jan Selby, 'Militarism and international relations in the 21st century', in Anna Stavrianakis and Jan Selby (eds), Militarism and International Relations: Political Economy, Security, Theory (London: Routledge, 2013 ), p. 3.

${ }^{21}$ Anna Stavrianakis, 'Legitimizing liberal militarism: Politics, law and war in the Arms Trade Treaty', Third World Quarterly, 37:5 (2016), pp. 840-65.

${ }^{22}$ Cooper, 'Humanitarian arms control and processes of securitization', p. 154.

${ }^{23}$ Mandy Turner, Neil Cooper, and Michael Pugh, 'Institutionalised and co-opted: Why human security has lost its way', in David Chandler and Nik Hynek (eds), Critical Perspectives on Human Security: Rethinking Emancipation and Power in International Relations (London: Routledge, 2010), p. 87.

${ }^{24}$ Ibid., p. 83.

${ }^{25}$ Neil Cooper and David Mutimer, 'Arms control for the $21^{\text {st }}$ century: Controlling the means of violence', Contemporary Security Policy, 32:1 (2011), pp. 11-12.

${ }^{26}$ UNDP, Human Development Report 1994 (Oxford: Oxford University Press, 1994), p. 40.

${ }^{27}$ Ibid., ch. 3 .

${ }^{28}$ Ibid.
} 
important step towards achieving human security.' ${ }^{29}$ While there was an emphasis on 'Third World disarmament', the report was clear that this must be one component of a 'blueprint for global disarmament'. ${ }^{30}$

So here we have an agenda for practical action on the weapons trade, challenging militarism to improve human security. The UNDP report identified the nation-statist ideologies of deterrence and territorial security, as well as the transnational practices of military assistance and proxy wars, as key causes of insecurity. Simultaneously, it reopened the debate about the link between security and development 'that had been closed since the somewhat sterile polemic around the link between disarmament and development' of the 1970s and 1980s. ${ }^{31}$ This earlier, now ostensibly out-dated debate surmised that 'the North (that is, both sides of the East-West conflict) should disarm, and devote the resources freed up by arms reduction to development in the South'. ${ }^{32}$ As part of this shift in debate, the move away from state-centred definitions of security was accompanied by an acknowledgment of the legitimate and crucial role of the state in providing security - especially as security was emphasised as a precondition for development. So the anti-militarist call that identified the state as a creator of insecurity was balanced against recognition of the legitimate role of the state in providing security. There was also a downgrading of military threats as a particular type of threat to human security: military threats do not appear as one of the seven main categories articulated in the report (economic, food, health, environmental, personal, community, political). Rather, threats from war (defined as 'threats from other states') are listed under the category of 'personal security', alongside threats of physical torture and ethnic tension, as well as crime, rape, domestic violence, and suicide. ${ }^{33}$

The analytical and political move made in the 1994 UNDP Report was to equate war with the state and move away from a concern with territorially based definitions of security and inter-state war, which it equates with militarism. There is a shift in focus to the spectrum of armed violence and non-conflict violence, which are to be remedied in the name of human security, in part through the (re)construction of legitimate coercive apparatuses. The shift away from militarism and towards human security claims to acknowledge the changing character of conflict and the role of the state in monopolising legitimate violence, without privileging it unthinkingly. Research in this vein has flourished in the years since the 1994 report, and brings significant advantages to bear over traditional state-centric analyses, such as the ability to account for the geographical diversity of rates of armed violence within as well as between states; sustained and distinct attention to gendered patterns of violence, including the specific character of femicide as a distinct form of violence; and the incorporation of questions of public health and socioeconomic inequality into discussion about weapons transfers. ${ }^{34}$

For all these developments, the human security agenda's take on war, conflict, and armed violence has not been without its critics. It has been described as the 'new orthodoxy' that is 'unable to provide the basis for a substantive change of the system of international security', despite finding 'the old language of interstate war and conflict ... lacking. ${ }^{35}$ Similarly, its

\footnotetext{
${ }^{29}$ Oscar Arias, 'A global demilitarization fund', in UNDP, Human Development Report 1994, p. 59.

${ }^{30}$ UNDP, Human Development Report 1994, p. 58.

${ }^{31}$ Keith Krause, 'Critical perspectives on human security', in Martin and Owen (eds), Routledge Handbook of Human Security, p. 79.

${ }^{32}$ Ibid.

${ }^{33}$ UNDP, Human Development Report 1994, p. 30.

${ }^{34}$ See, for example, Vanessa Farr, Henry Myrttinen, and Albrecht Schnabel (eds), Sexed Pistols: The Gendered Impacts of Small Arms and Light Weapons (Tokyo: United Nations University Press, 2009); Geneva Declaration, Global Burden of Armed Violence (Cambridge: Cambridge University Press, 2015 [orig. pub. 2011]); Robert Muggah and Keith Krause, 'Closing the gap between peace operations and post-conflict insecurity: Towards a violence reduction agenda', International Peacekeeping, 16:1 (2009), pp. 136-50.

${ }^{35}$ Ryerson Christie, 'Critical voices and human security: To endure, to endanger or to critique?', Security Dialogue, 41:2 (2010), pp. 169, 172.
} 
emphasis on 'progressive' initiatives such as 'eliminat[ing] certain types of weapons' stands accused of failing to adequately examine 'the pathologies inherent in the structure of the international system' that generate such challenges. ${ }^{36}$ And when the 'human' in human security is naturalised as masculine, the inclusion of novel threats and new actors leaves the parameters of security untouched, meaning that 'state-based, militarised security remains unchallenged'. ${ }^{37}$ Feminist scholars have critiqued the gendered concepts and practices of war, peace, militarisation, peacekeeping and soldiering, going well beyond the human security framework in the process. $^{38}$

Feminist critiques that challenge the parameters of human security can usefully be combined with postcolonial accounts of IR that emphasise the ways in which the discipline 'can both deny empire while simultaneously normalizing an imperial perspective on the world' ${ }^{39}$ Some of the main themes of the human security agenda are illustrative of the need for an imperial perspective in how we understand the challenges facing weapons control. By this I mean interpreting them with the aid of scholarship that challenges methodological nationalism and Eurocentrism in its analysis, mobilises feminist critiques of militarism, and puts the legacy of empire and colonialism, and the racial, gendered, and classed politics of imperial control, front and centre in its assessment of contemporary challenges. ${ }^{40}$ Deploying such resources gives us a chance to rethink some of the key assumptions around human security and the prospects for regulating weapons circulation.

Three core themes of the human security agenda are ripe for an imperial critique. First, the claim that the character of conflict has changed, from inter-state war towards internal conflict, has become axiomatic in much of IR, including the human security literature. ${ }^{41}$ The greatest threats to human security are deemed to stem from internal conflict and criminal violence, or the state itself, rather than from an external adversary as per the traditional security agenda. As such, 'international security traditionally defined - territorial integrity - does not necessarily correlate with human security'. ${ }^{42}$ Second, the changing character of conflict requires a shift in the referent object of security, according to the human security agenda: away from the state and inter-state war, and towards the individual and the broader range of threats they face. ${ }^{43}$ And third, the human security agenda nonetheless emphasises the importance of the state's monopoly on

\footnotetext{
${ }^{36}$ Edward Newman, 'Critical human security studies', Review of International Studies, 36:1 (2010), p. 93.

${ }^{37}$ Annick T. R. Wibben, 'The promise and dangers of human security', in Jonna Nyman and Anthony Burke (eds), Ethical Security Studies: A New Research Agenda (London: Routledge, 2016), p. 107.

${ }^{38}$ Aili Mari Tripp, 'Toward a gender perspective on human security', in Aili Mari Tripp, Myra Marx Ferree, and Christina Ewig (eds), Gender, Violence, and Human Security: Critical Feminist Perspectives (New York: New York University Press, 2013), p. 10.

${ }^{39}$ Tarak Barkawi, 'Empire and order in International Relations and security studies', in Robert A. Denemark (ed.), The International Studies Encyclopedia (Hoboken, NJ: Wiley Blackwell, 2010), pp. 1360-79; also Branwen Gruffydd Jones, “'Good governance" and "state failure": Genealogies of imperial discourse', Cambridge Review of International Affairs, 26:1 (2013), pp. $49-70$.

${ }^{40}$ On weapons issues specifically, see Shampa Biswas, Nuclear Desire: Power and the Postcolonial Nuclear Order (Minneapolis: University of Minnesota Press, 2014); Ritu Mathur, 'Sly civility and the paradox of equality/inequality in the nuclear order: a post-colonial critique', Critical Studies on Security, 4:1 (2016), pp. 57-72. More widely, see, for example, Gurminder Bhambra, Rethinking Modernity: Postcolonialism and the Sociological Imagination (London: Palgrave Macmillan, 2007); Julian Go, 'For a postcolonial sociology', Theory and Society, 42:1 (2013), pp. 25-55; A. G. Hopkins, 'Back to the future: From national history to imperial history', Past and Present, 164 (1999), pp. 198-243; Amina Mama and Margo Okazawa-Rey, 'Militarism, conflict and women's activism in the global era: Challenges and prospects for women in three West African contexts', Feminist Review, 101 (2012), pp. 97-123.

${ }^{41}$ The key figure here is Mary Kaldor, central to both the new wars literature and the human security agenda. Mary Kaldor, New and Old Wars: Organized Violence in a Global Era (Redwood City: Stanford University Press, 1999); Mary Kaldor, 'What is human security?', in David Held (ed.), Debating Globalization (Oxford: Polity Press, 2005), pp. 175-90.

${ }^{42}$ Newman, 'Critical human security studies', p. 79.

${ }^{43}$ Ramesh Thakur, 'A political worldview', Security Dialogue, 35:3 (2004), p. 347.
} 
legitimate violence and role in security provision. ${ }^{44}$ Yet the circumstances have been transformed with the end of the Cold War. Kaldor attributes a 'profound restructuring of political authority' to the new wars, and sees human security as an opportunity for 'reconstructing political authority in the context of the processes we call globalisation'. ${ }^{45}$ Hence the need for security sector reform (SSR), demobilisation, disarmament, and reintegration (DDR) and other reforms of coercive practices and apparatuses.

Each of these three themes is premised on the significance of the rupture that occurred with the end of the Cold War. But understanding the Cold War as predominantly an East-West ideological and geopolitical confrontation marginalises longer historical patterns of North-South power relations and conflict, and of hot war in the South. And the increased focus on internal conflict, while fruitful in terms of changing the scale of analysis, risks disconnecting the micropolitics of violence from broader systems and structures of war preparation, ignoring one of the key lessons of feminist scholarship, which is that the scales or so-called levels of analysis are interdependent. As Laura Sjoberg and Sandra Via put it, 'absolutely distinguishing between the personal, national and international level of war and militarism lacks conceptual and empirical rigor at best': feminist attention allows us to understand both the impact of war and militarism on people (especially, but not only, women) as well as the gendered construction of war and militarism. ${ }^{46}$

A longer historical view that is not hamstrung by a state-centric ontology allows us to see that arms transfer practices have long been part of the simultaneously transnational and asymmetrical constitution of force. Historical scholarship on the arms trade emphasises the importance of decolonisation as the shift from empire to a system of formally sovereign states in which NorthSouth power asymmetries continue to resonate. One of the key transformations in weapons transfer practices that came with decolonisation was a shift on the part of the Soviet Union and China from support for national liberation movements, to the defence of sovereignty as a means of resisting US-led domination, in either anti-capitalist or anti-imperialist modes. ${ }^{47}$ The supply of weapons and military training was a common feature of both Soviet and US relations with the Third World: despite their differences, North-South politico-military relations had much in common between the two blocs. ${ }^{48}$

Ostensibly new or transformed challenges of the post-Cold War era, such as Somali piracy, new wars in Africa, or insurgency and counterinsurgency in Afghanistan, are thus better understood in postcolonial terms, with militarised transnational continuities as well as changes associated with the end of superpower rivalry. ${ }^{49}$ Amina Mama and Margo Okazawa-Rey emphasise the continuities between colonial and contemporary militarism that not only led them to prefer the terminology of postcolonial conflicts over that of new wars, but also emphasise the fundamentally gendered characteristics of the physical and structural violence at stake. ${ }^{50}$ And as Cooper argues, arms control regimes have long featured both 'proscription and permission' 51

\footnotetext{
${ }^{44}$ Newman, 'Critical human security studies', p. 79.

${ }^{45}$ Mary Kaldor, 'Human security: Political authority in a global era', in Martin and Owen (eds), Routledge Handbook of Human Security, pp. 66, 68.

${ }^{46}$ Laura Sjoberg and Sandra Via, 'Conclusion: the interrelationship between gender, war, and militarism', in Sjoberg and Via (eds), Gender, War and Militarism, pp. 231-4. See also, for example, J. Ann Tickner, 'You just don't understand: Troubled engagements between feminists and IR theorists', International Studies Quarterly, 41:4 (1997), pp. 611-32.

${ }^{47}$ See, for example, Anne Gilks and Gerald Segal, China and the Arms Trade (New York: St Martin's Press, 1985); Alvin Z. Rubinstein, Moscow's Third World Strategy (Princeton: Princeton University Press, 1988); Jeremy Friedman, Shadow Cold War: The Sino-Soviet Competition for the Third World (Chapel Hill: University of North Carolina Press, 2015).

${ }^{48}$ Noam Chomsky and Edward S. Herman, The Washington Connection and Third World Fascism (Boston: South End Press, 1979); Yuriy Kirshin, 'Conventional arms transfers during the Soviet period', in Ian Anthony (ed.), Russia and the Arms Trade (Oxford: Oxford University Press, 1998), pp. 38-70.

${ }^{49} \mathrm{Chew}$, Arming the Periphery; Mama and Okazawa-Rey, 'Militarism, conflict and women's activism in the global era'.

${ }^{50}$ Mama and Okazawa-Rey, 'Militarism, conflict and women's activism in the global era'.

${ }^{51}$ Cooper, 'Race, sovereignty and free trade'.
} 
operating in tandem, challenging the optimism of accounts premised on the end of the Cold War as the changed permissive factor that allows humanitarian concerns to be the core objective of weapons control. This emphasis on history and power generates scepticism about the optimism and presentism of most accounts of the emergence of the ATT, and the linear, benevolent account of history found therein. ${ }^{52}$ A longer historical perspective allows us to see how state security (whether national or imperial) and (what is today called) human security have long been two sides of the same coin.

There are thus continuities of imperial forms of practice despite the turn to formal sovereignty. A focus on the systematic or organised and North-South character of much armed violence is not to return to Cold War politics or the 'sterile polemic' of past debates about weapons issues mentioned earlier. Rather, it is to emphasise that historical weapons supply routes and power relations continue to resonate; that massive and uneven levels of global military spending and proxy wars continue to matter; and that clients continue to use weapons in ways that are often unanticipated by patrons. Ostensibly civil or internal wars are enmeshed in wider regional and international projects. ${ }^{53}$ There are internationalised sources of much of what counts as domestic, civil or intra-state, including colonial legacies and internationalised weapons supply chains. In many accounts, human security has been mobilised as an attempt to 'cope with [the] pathological results' of how security has been defined in postcolonial states in the South. ${ }^{54}$ Yet this encourages internalist analysis that sees the problems of armed violence as having their sources primarily within the global South. In conceding the terms of debate to 'traditional' security studies, and seeking to shift inwards from the state to the individuals living within it, rather than critiquing the conception of the international system, the human security agenda continues to 'occlude and distort imperial relations' in the way that more traditional 'Westphalian terms of reference' do. ${ }^{55}$

In the human security agenda's account of the shift from wars between states to wars within them, war falls off the agenda as it is deemed analytically outdated and politically regressive. Yet neo-realist, Cold War accounts of national security were never adequate, and in trying to overcome them, many human security accounts take them at face value and get the critique wrong. With its emphasis on the enduring power of war preparation, the concept of militarism suggests that much contemporary violence remains coordinated or facilitated (by state, paramilitary, militia, or other organised actors), and systematic within society, despite the shift towards discussion of armed violence and intentional homicide, which is suggestive of disorganised violence. So how are we to mobilise the concept of militarism in light of the imperial turn, in ways that help us think more productively about weapons control?

First is to defend the use of the concept at all. According to Mary Kaldor, the concept of militarism has outlived its usefulness as it is 'drawn from the Cold War and before': the changes with the end of the Cold War necessitate new terms. ${ }^{56}$ To capture the ways that organised violence blurs state/non-state and national/foreign boundaries, whether in the form of paramilitary groups, organised crime or terrorist cells, or in the form of peacekeeping troops, Kaldor coins the terms 'Netforce' and 'Protectionforce' respectively. ${ }^{57}$ Kaldor restricts the concept of militarism to 'the new American militarism' and the 'neo-modern militarism' ('the evolution of classical military forces in large transition states' practising inter-state war or counterinsurgency)

\footnotetext{
${ }^{52}$ Ibid.

${ }^{53}$ See, for example, Marielle Debos, Living by the Gun in Chad: Combatants, Impunity and State Formation (London: Zed, 2016).

${ }^{54}$ Krause, 'Critical perspectives on human security', p. 85.

${ }^{55}$ Barkawi, 'Empire and order in IR and security studies'.

${ }^{56}$ Mary Kaldor, 'Beyond Militarism, Arms Races and Arms Control' (December 2001), available at: \{http://essays.ssrc.org/ sept11/essays/kaldor.htm\}.

${ }^{57}$ Ibid.
} 
of states such as Russia, China, and India. ${ }^{58}$ But in differentiating some types of organised violence as not-militarism, we lose the opportunity to compare them, to see the overlaps, similarities, and differences in modes of organised violence. Feminists have long been able to capture this with the concept of militarism, showing us that it is not quite so easy to set aside "ordinary" aggression, force or violence as "not war" 59 - especially when we pay attention to the experience of violence in the global South. ${ }^{60}$

Second, and relatedly, the specificities of combinations of actors, degrees of state support, and so on, are subject to empirical and historical specificity, and a common rubric of militarism helps us understand similarities and differences between them. Working in a historical sociological tradition, Bryan Mabee and Srdjan Vucetic draw up a typology of forms of contemporary militarism. ${ }^{61}$ They contrast Michael Mann's concept of civil society militarism - 'the use of organized military violence in pursuit of social goals that is "state-supported, but not state-led" 62 - to 'nation-state militarism' in both its authoritarian and liberal forms; to 'neoliberal militarism' structured around socioeconomic liberalisation; and to 'exceptionalist militarism' seen in practices associated with the War on Terror. Feminists tend not to operate in such formal typological ways, but have long been articulating the idea of war and militarism as a spectrum or a system, in which the forms, intensities, and characteristics may vary, but the gendered basis of violence is central. ${ }^{63}$ And a focus on militarism can be usefully mobilised to consider the connections and feedback loops between Northern and Southern practices, giving a more internationalised account that is better attuned to the operation of power in contexts of armed violence. Indeed, Rita Abrahamsen refers to 'global militarism in Africa' because 'while militarism is always specific (and often national), it is also simultaneously global', and the 'analytical challenge is to capture at one and the same time the global and the local, and their intersection in particular locations' ${ }^{64}$

Third, while I want to defend the concept, and think about types of militarism in relation to each other, it is crucial to acknowledge that contemporary militarism and human security have shaped each other in the last twenty years. Human security, with its emphasis on human rights and IHL, has become a mediating element in the relation between war and society. Post-Cold War processes of democratisation have 'often coincided with new forms of militarism' that tend to be analysed under the rubric of policy-oriented concepts such as security sector reform. ${ }^{65}$ As Abrahamsen argues, 'The securitization of underdevelopment ... is the condition of possibility for a global militarism justified in the name of human security and development. ${ }^{66}$ We must take heed of Abrahamsen's warning that 'Paradoxically, transformations that initially entailed a critique of militarization and militarism have ended up according a new importance to security actors and laying the groundwork for new expressions of militarization and militarism. ${ }^{67}$

\footnotetext{
${ }^{58}$ Ibid.

${ }^{59}$ Cockburn, 'Gender relations as causal in militarization and war', p. 146.

${ }^{60}$ Cynthia Cockburn and Cynthia Enloe, 'Militarism, patriarchy and peace movements', International Feminist Journal of Politics, 14:4 (2012), pp. 550-7.

${ }^{61}$ Bryan Mabee and Srdjan Vucetic, 'Varieties of militarism: Towards a typology', Security Dialogue, 49:1-2 (2018), pp. 96-108.

${ }^{62}$ Mann, quoted in ibid., p. 102.

${ }^{63}$ Cockburn, 'Gender relations as causal in militarization and war'; Harriet Gray, 'Domestic abuse and the public/private divide in the British military', Gender, Place and Culture: a Journal of Feminist Geography, 23:6 (2016), pp. 912-25; Tripp, 'Toward a gender perspective on human security', p. 9; Jacqui True, The Political Economy of Violence Against Women (Oxford: Oxford University Press, 2012).

${ }^{64}$ Rita Abrahamsen, 'Return of the generals? Global militarism in Africa from the Cold War to the present', Security Dialogue, 49:1-2 (2018), p. 20.

${ }^{65}$ Robin Luckham, 'Democratic strategies for security in transition and conflict', in Robin Luckham and Gavin Cawthra (eds), Governing Insecurity: Democratic Control of Military and Security Establishments in Transitional Democracies (London: Zed, 2003), p. 3.

${ }^{66}$ Abrahamsen, 'Return of the generals?', p. 27.

${ }^{67}$ Ibid., p. 28.
} 
Human security has - against its self-image as a progressive social force - facilitated a resurgent as well as transformed militarism.

\section{Controversies and silences in the Arms Trade Treaty}

Having considered the relationship between militarism and human security, I now turn to the specifics of the ATT and the ramifications for weapons control. The impetus for the ATT lay in the human security agenda. The call for a treaty to regulate the arms trade came from a coalition of NGOs who, allied with a group of Nobel Peace Laureates led by former Costa Rican President Oscar Arias, mobilised states and civil society from Europe, sub-Saharan Africa and Latin America to push for the treaty via the UN. Their goal was a treaty that would provide a framework for reducing the number of lives lost and damaged through un- or under-regulated arms transfers that exacerbate conflict, armed violence, and organised crime. They won several victories during the drafting of the treaty: the inclusion of the reduction of human suffering in its object and purpose; the mention of 'armed violence' as well as 'armed conflict' in the Preamble, which broadens the obligations on states beyond legal definitions of conflict; the first inclusion of GBV as a criterion in an international treaty; and the inclusion of SALW in the scope of the treaty.

Alongside the human security agenda, many states - including some of the treaty's strongest proponents - also articulated a political economy-based position on the purpose of the treaty. Encapsulated in the idea of levelling the playing field - creating common regulatory standards to prevent under-cutting - this vision sees weapons transfers in terms of defence-industrial policy and the political economy of the global arms market. This is seen as compatible with human security: it provides 'more economically based reasons for supporting the international, normbuilding approach' associated with human security. ${ }^{68} \mathrm{EU}$ member states expended significant energy trying to get the US, as the world's largest arms exporter, on board. And the UK, France and US, in particular, were keen to incorporate China and emerging Southern exporters into a common regulatory regime. Although not highly visible during the treaty negotiations, the arms industry of Western states - for the most part formally (but not substantively) separate from the state, unlike in many non-Western states - also took this position, on the basis that the treaty could bring 'a definite comparative advantage to the defence industry'. ${ }^{69}$

A third understanding of the ATT's purpose is based on sovereignty: the concern that the treaty may hamper states' ability to import weapons and transfer them as they see fit. This account was primarily articulated by Southern states, often with nationalised military industries. These include growing military producers such as China and Brazil; major importers such as India; regional antagonists such as Egypt, Israel, Pakistan and India; leftist Latin American states such as Venezuela and Cuba; and the three states that voted against the treaty, North Korea, Iran, and Syria. Sovereignty was also a strong theme of the US position, however: weapons transfers are a 'sovereign decision' premised on state's right to engage in foreign policy as it sees fit, and its opposition to any overarching authority being able to tell states how to interpret the treaty. ${ }^{70}$ In this account, there is emphasis on states' legitimate interests in trading materiel, equipment, and technology for political, security, economic and commercial reasons.

\footnotetext{
${ }^{68}$ Roberto Garcia Moritán, 'Article 1: Object and purpose', in Brian Wood and Clare da Silva (eds), Weapons and International Law: The Arms Trade Treaty (Brussels: Larcier, 2015), p. 24. On the interplay between political economy and human security concerns, see Susanne Therese Hansen, 'Taking ambiguity seriously: Explaining the indeterminacy of the European Union conventional arms export control regime', European Journal of International Relations, 22:1 (2016), pp. $192-216$.

${ }^{69}$ Elli Kytömäki, 'The Defence Industry, Investors and the Arms Trade Treaty' (December 2014), p. 3, available at: \{https:// www.chathamhouse.org/publication/defence-industry-investors-and-arms-trade-treaty\} accessed 16 February 2018.

${ }^{70}$ Arms Trade Treaty Legal blog, 'Day One of the Prepcom' (12 July 2010), available at: \{http://armstradetreaty.blogspot.co. uk/2010/07/day-1-of-prepcom.html\} accessed 17 January 2018.
} 
The human security, political economy and sovereignty orientations towards the control of weapons circulation demonstrate some of the variety of forms of militarism in the contemporary world. They do not map directly on to existing types but, as Mabee and Vucetic explain, this empirical diversity helps us to move away from primarily statist conceptualisations of militarism. ${ }^{71}$ Human security can be well described as an expression of liberal militarism, which features justifications for the use of force based on values and morals, accompanied by the use of law to legitimise it; a strong commitment to military production across war - and peacetime; and a capital - and technology-intensive orientation to war preparation. ${ }^{72}$ Human security is thus organically linked to particular conceptions of political economy - as evidenced by the ostensible compatibility between the promotion of arms exports and support for human security as articulated by some states, noted above.

Sovereigntist orientations towards the ATT are well encapsulated by the concept of nationstate militarism, often but not always authoritarian in form. Again, this has political economic dimensions - the "state-led economic and social mobilization of "destructive" forces" ${ }^{73}$ of nationstate militarism is reflected in the state ownership and direction of the arms industry in many states articulating a sovereigntist account of the treaty, and in the US position, where industry is formally private but arms exports are a matter of state policy. Often deemed retrograde, nationstate militarism 'consistently reasserts itself and needs to be accounted for' ${ }^{74}$ Its persistence should be read as a means of agency under conditions of hierarchy: in an officially equal but substantively unequal international system, marked by the ongoing legacies of colonial rule and contemporary practices of state formation and internal colonisation, the enduring power of sovereignty continues to occlude North-South relations, whether articulated by the US or states of the global South.

Given the different accounts of what the treaty was for, and as would be expected during any treaty negotiation, there was significant diplomatic contestation during the treaty process. While there was some fluidity between the positions, the trifecta of sovereignty, political economy, and human security remains a useful heuristic for understanding the broad differences in orientation towards the treaty. In what follows, I identify three key controversies and one silence that shaped the eventual treaty text. I want to demonstrate that these issues go beyond diplomatic or technical contestation. Rather, they indicate deeply political processes in which different modes of contemporary militarism - including one inflected by human security - come into conflict over specific empirical issues.

\section{Defining the 'illicit and unregulated' trade}

The ATT is designed to prevent and eradicate the 'illicit and unregulated' trade in weapons. The term 'illicit' is not defined in the treaty text, due to dispute over its meaning that has simultaneously facilitated and plagued multilateral action on weapons issues for over two decades. ${ }^{75}$ That is, the 'illicit and unregulated' formulation is both the basis of any traction the treaty might have, and a key source of disagreement as to what the treaty means in practice. Major nonWestern weapons exporters (Russia and China) and importers (such as India and Middle Eastern states) most strongly articulated a narrow, legalistic, sovereignty-based position during negotiations. For them, illicit transfers are unauthorised transfers to non-state actors, in particular terrorists $^{76}$ - a position based on their domestic battles over secession, territorial integrity and the

\footnotetext{
${ }^{71}$ Mabee and Vucetic, 'Varieties of militarism', p. 104

${ }^{72}$ Stavrianakis, 'Legitimizing liberal militarism', p. 845.

${ }^{73}$ Mabee and Vucetic, 'Varieties of militarism', p. 101.

${ }^{74}$ Ibid., p. 102.

${ }^{75}$ See successive editions of the Small Arms Survey (Geneva: Small Arms Survey) for an account of how international public policy has handled the definitional issues.

${ }^{76}$ Moritán, 'Article 1: Object and purpose', p. 24.
} 
monopoly on legitimate violence, and their foreign policy interest in supporting state sovereignty. For them, 'illicit' means illegal, unlawful, or unauthorised.

A variety of states specifically wanted a ban on transfers to non-state actors to be written into the treaty text as part of the illicit trade formulation. For states that articulated a sovereigntybased position, such as Russia, China and India, such a ban was an anti-terrorism necessity. All three abstained from the final vote on the treaty, citing the failure to include such a ban in relation to their own problems with non-state actors and the war in Syria. ${ }^{77}$ A handful of predominantly Latin American and sub-Saharan African states, meanwhile, who are predominantly importing or transit states and face problems of organised crime and armed violence, also wanted a ban. ${ }^{78}$ For such states, transfers to non-state actors are the key problem of illicit trade, either for anti-terrorism, organised crime, or armed violence reasons.

States adopting a narrow position on the illicit trade reject criticism of their weapons transfer practices on two grounds. First, by pointing to the fact transfers are authorised: as an expression of state policy, they are, by definition, responsible. And second, by rebutting criticism from Western actors (state or civil society) as politically motivated: they tended to view arguments about human rights and humanitarianism as a political tool of western states. ${ }^{79}$ In this, the ATT negotiations are fairly typical of the ways in which non-Western states are sceptical of initiatives that would threaten their sovereign status.

They are also indicative of the ways that nation-state militarism is both masculinist and shot through with North-South relations: the emphasis on the weaponised defence of sovereignty by states who deem themselves disadvantaged within the international state system and capitalist global economy, are engaged in their own postcolonial or other battles over national territorial integrity, and/or resisting Western domination and hypocrisy. As examples, the Indian delegation insisted on the exclusion of defence cooperation agreements from the provisions of the treaty ${ }^{80}$ and then abstained on the final vote on the treaty. The Chinese delegation, under pressure from the military, insisted on excluding military gifts from the definition of arms transfers, ${ }^{81}$ as a means of protecting military assistance and bilateral relations with other developing states. Several Southern states also insisted on the exclusion of any language of socioeconomic development, and on the insertion of language of 'objective and non-discriminatory' application of treaty criteria. States' statements to the UN set out the context in which these demands make sense: fear that discriminatory and subjective criteria will be used as a tool of interference; opposition to Western double standards and hypocrisy; concern that the ATT will be used as a means of curtailing the right to trade in arms and that law will be used as cover for political decisions; fear of regime change; opposition to occupation and the use of force; and emphasis on asymmetry in production. ${ }^{82}$

\footnotetext{
${ }^{77}$ Colum Lynch, 'The Arms Trade Treaty's doubters', Foreign Policy (2 April 2013), available at: \{http://turtlebay.foreignpolicy.com/posts/2013/04/02/the_arms_trade_treaty_doubters\}; Satish Chandra, 'Appraisal of Arms Trade Treaty', The New Indian Express (18 April 2013), available at: \{http://newindianexpress.com/opinion/Appraisal-of-Arms-TradeTreaty/2013/04/18/article1549671.ece\}; Moscow Times, 'Russia warns it may not sign landmark UN Arms Treaty' (4 April 2013), available at: $\{$ http://www.themoscowtimes.com/news/article/russia-warns-it-may-not-sign-landmark-un-arms-treaty/ 477890.html\}.

${ }^{78}$ Sarah Parker, 'Analysis of States' Views on an Arms Trade Treaty', UNIDIR (October 2007), available at: \{http://www. unidir.org/files/publications/pdfs/analysis-of-states-views-on-an-arms-trade-treaty-332.pdf\}. Note that the ECOWAS Convention on Small Arms and Light Weapons, their Ammunition and other Related Material, for example, already bans the transfer of SALW, including to non-state actors (when not explicitly authorised by the importing state).

${ }^{79}$ Anna Stavrianakis, 'Progressives, pariahs and sceptics: Who's who in the Arms Trade Treaty?', e-International Relations (29 May 2013), available at: \{http://www.e-ir.info/2013/05/29/progressives-pariahs-and-sceptics-whos-who-in-the-armstrade-treaty/\}.

${ }^{80}$ Kanwal Sibal, 'Guns, helicopters and the treaty', The Telegraph (27 April 2013), available at: \{http://www.telegraphindia. com/1130427/jsp/opinion/story_16830361.jsp\#.Vrs1I_mLTWJ\}.

${ }^{81}$ Mark Bromley, Mathieu Duchâtel, and Paul Holtom, 'China's Exports of Small Arms and Light Weapons', SIPRI Policy Paper 38 (October 2013); Paul Holtom, 'Article 2: Scope', in Wood and da Silva (eds), Weapons and International Law, p. 33.

${ }^{82}$ States' statements to the UN during the negotiating process, available at: $\{\mathrm{http}: / / \mathrm{www} . u n . o r g / \mathrm{disarmament} / \mathrm{ATT} /\}$.
} 
Set against the legalistic, sovereignty-based definition of the illicit trade was a broader definition promoted by European and several sub-Saharan African, Latin American and Caricom states, the US, and NGO advocates and campaigners. In this, the use to which weapons are put is more important than the legal identity of the recipient. 'Illicit' thus means that transfers can be authorised by states, but still be irresponsible and thus illegitimate because they contribute to human rights and IHL violations. The Africa Group, negotiating on behalf of most of subSaharan Africa, initially articulated a more state-centric vision of the ATT until lobbying from African civil society and churches, Control Arms and other maximalist states' persuaded them to change position and tone to 'reflect human security concerns ${ }^{\prime 83}$ alongside the demand for a ban on transfers to non-state actors. This broader definition resonates with a feminist critique of militarism that seeks to make connections between the legal and the illicit: just because transfers are authorised does not make them legitimate.

However, on the flipside, a use-based definition of the illicit trade also means that transfers to non-state actors can be argued to be legitimate: for the US and European states, supplying nonstate actors is not synonymous with the illicit trade. EU member states and the US already have regulatory systems based on end-use practices, make strong normative claims about the consistency between their values and arms export policies, and yet also regularly export weapons (to states and non-state actors) that violate human rights. ${ }^{84}$ The US government (and, less vocally, European states) was unequivocally opposed to a ban on transfers to non-state actors (while also articulating an anti-terrorism position), so as to retain freedom of action in national security and foreign policy, and in line with its redline on controls on civilian possession. ${ }^{85}$ The ways in which this broader use-based definition can be mobilised to both restrain and promote arms transfers shows the importance of foregrounding the imperial dimensions of a feminist argument. That is, while a use-based argument can be mobilised to restrict a greater range of transfers by delegitimising those that are authorised but still irresponsible, activists need to be alert to the risk of cooption by states who themselves have problematic transfer practices and seek to mobilise liberal commitments for reputational purposes. ${ }^{86}$

The main axis of contestation in the definition of the purpose of the treaty is the role of the state in authorising or directing transfers, whether overtly or covertly. In the eventual treaty text, the US's refusal to countenance a ban won out; there is no explicit ban on transfers to non-state actors in the treaty. The compromise was that the Preamble to the treaty underlines the need to prevent the diversion of weapons to the illicit market, 'or for unauthorized end use and end users, including in the commission of terrorist acts'. This allows states to pursue a narrow or broad definition of the illicit trade, focused on use or identity, as they prefer; and to include a ban on non-state actors in their national systems if they so wish. This diplomatic fudge suggests that the overall framing of the treaty as one designed to combat the illicit and unregulated trade should

\footnotetext{
${ }^{83}$ Bolton and James, 'Nascent spirit of New York or ghost of arms control past?', p. 7.

${ }^{84}$ Jennifer Erickson, 'Market imperative meets normative power: Human rights and European arms transfer policy', European Journal of International Relations, 19:2 (2013), pp. 209-34; Susanne Therese Hansen and Nicholas Marsh, 'Normative power and organised hypocrisy: European Union member states' arms export to Libya', European Security, 24:2 (2015), pp. 264-86; Richard A. I. Johnson and Spencer L. Willardson, 'Human rights and democratic arms transfers: Rhetoric versus reality with different types of major weapon systems', International Studies Quarterly (2018), available at: \{https://doi. org/10.1093/isq/sqx077\}; Richard Perkins and Eric Neumayer, 'The organized hypocrisy of ethical foreign policy: Human rights, democracy and Western arms sales', Geoforum, 41 (2010), pp. 247-56.

${ }^{85}$ US Department of State, 'Elements of an Arms Trade Treaty' (20 January 2017), available at: \{https://www.state.gov/t/ isn/rls/fs/2017/266979.htm\}.

${ }^{86}$ Controversies over the tensions between Swedish and Canadian commitments to both feminist foreign policy and arms sales are interesting in this regard; see, for example, Jacqui True, 'Why we need a feminist foreign policy to stop war', The Conversation (20 April 2015), available at: \{https://www.opendemocracy.net/5050/jacqui-true/why-we-need-feminist-foreign-policy-to-stop-war\}; Srdjan Vucetic, 'A nation of feminist arms dealers? Canada and military exports', International Journal: Canada’s Journal of Global Policy Analysis, 72:4 (2017), pp. 503-19.
} 
not be seen as a human security victory over militarism, but rather an indication of how one form of contemporary militarism has taken human security on board and is in contestation with other forms.

\section{Treatment of human rights and $\mathrm{IHL}$}

If the 'illicit and unregulated trade' formulation provides the skeleton for the ATT, Articles 6 and 7 form its heart. They set a 'floor not a ceiling ${ }^{87}$ of basic standards, in the form of prohibitions based on international law (Article 6), and national risk assessment processes (Article 7). Weapons transfers that would violate UN arms embargoes or would be used in genocide, crimes against humanity or other war crimes, are prohibited under Article 6. If a transfer is not prohibited, States Parties wishing to export weapons must conduct a risk assessment against a set of criteria that includes IHL and human rights, under the terms of Article 7. IHL and human rights standards are now brought together in legally binding provisions to cover situations of armed conflict and also non-conflict situations; and risks around GBV must be considered when licensing exports.

The combination of international human rights and humanitarian law being applied to weapons transfers is widely considered a major human security victory. Yet the human security gains have an ambivalent relationship to militarism. Article 7 introduces a balancing act into licensing decisions. When conducting a risk assessment, the first consideration exporting states are bound by is whether the transfer 'would contribute to or undermine peace and security' ${ }^{88}$ The possibility that an export could contribute positively to peace and security is not included in antecedent regional regimes such as the EU Common Position, and was inserted at the US delegation's insistence. States Parties still have to proceed to the second part of the test, but the ATT has an inbuilt opportunity for them to make a peace and security claim in favour of exports. Under the remainder of Article 7, if there is an 'overriding' risk of serious human rights violations and other ills, states must not authorise the transfer. Again, this language is less restrictive than some existing regimes - the EU Common Position language is of 'significant' risk, for example - and was inserted at the behest of the US delegation, in line with its insistence that arms exports are often 'vital for the maintenance of peace and security'. ${ }^{89}$ There are a variety of possible interpretations of 'overriding' risk in state practice: as 'more likely to materialise than not', as 'substantial' risk, or as positive consequences being outweighed by negative ones. ${ }^{90}$ While some states may choose to act restrictively, the wording was designed to keep the door open for freedom of action by the US, as well as due to opposition to the lower bar of 'substantial risk' from the US, Russia, China, India, and others. ${ }^{91}$

Article 7 also includes language about weapons being used to 'commit or facilitate' human rights and IHL violations, which goes beyond existing national and regional regimes and has greater demilitarising potential. The weapons 'may be one or more steps removed from the actual violation,, ${ }^{92}$ which means the concept of facilitation could open greater space to challenge weapons transfers. This is where the treatment of GBV in the treaty becomes especially pertinent. Article 7.4 obliges exporting states to 'take into account the risk' of weapons 'being used to commit or facilitate serious acts of gender-based violence or serious act of violence against

\footnotetext{
${ }^{87}$ This phrase circulated widely among both state and non-state participants in and observers of the negotiations.

${ }^{88} \mathrm{UN}$, The Arms Trade Treaty, Article 7.1.a.

${ }^{89}$ Clare Da Silva and Brian Wood, 'Article 7: Export and export assessment', in Wood and da Silva (eds), Weapons and International Law, p. 118.

${ }^{90}$ ATT Monitor, ATT Monitor Report (2015), ch. 1.1, p. 42, available at: $\{$ http://armstreatymonitor.org/current/wpcontent/uploads/2015/08/Full-Annual-Report.pdf\}; Andrew Clapham, Stuart Casey-Maslen, Gilles Giacca, and Sarah Parker, The Arms Trade Treaty: A Commentary (Oxford: Oxford University Press, 2016), p. 277.

${ }^{91}$ Da Silva and Wood, 'Article 7: Export and export assessment', p. 120.

${ }^{92}$ Clapham et al., The Arms Trade Treaty, p. 255.
} 
women and children'. ${ }^{93}$ Objections from some states (notably the Holy See, which has observer status at the UN, and Middle East and North African states) led to a 'slightly messy compromise' in the treatment of GBV. ${ }^{94}$ Exporting states are required to 'take into account' the risk of GBV in their national risk assessment process; but exporters are only legally obliged to refuse exports if the result of the assessment shows that the risk is of serious violations of IHL or international human rights law. Given that many acts of GBV are indeed violations of IHL and human rights law, ${ }^{95}$ most commentators see 7.4 as a win for anti-GBV activism as exporters are required to assess GBV risks, ${ }^{96}$ 'mak[ing] it harder for perpetrators to access weapons'.

Nonetheless, the treatment of GBV illustrates the challenges of addressing militarism. Cynthia Enloe describes Article 7.4 as 'a transnational feminist success', 'buried in [the ATT's] thirteen pages of formal diplomatic language. ${ }^{98}$ WILPF characterises the forms of harm caused by the arms trade in terms of sexual violence, repression and state violence, and homicide and domestic violence, ${ }^{99}$ illustrating feminist arguments about war as a continuum or a system. This connects up 'domestic' or intimate partner violence to war, and 'internal' repression and state violence to 'external' war, exposing what Enloe calls 'the causal connections between group armed violence and violence perpetrated inside homes and families'. ${ }^{100}$ But alongside the inevitable diplomatic and bureaucratic politics of implementation, there is the question of how this broader feminist, anti-militarist critique could be operationalised, not least because of the raising of the bar in the treaty text, such that GBV risks have to constitute serious violations of IHL or IHRL to be a reason to deny exports. As Paul Kirby puts it: 'is there ever a conflict where arms flows could not be said to facilitate serious acts of gender-based violence - harms strongly correlated with, but not necessarily inflicted by, the deployment of weaponry? Is the use of white phosphorous 'gender-based' because it is indiscriminate, and therefore likely to inflict harm on innocent 'womenandchildren'? ... Are massacres of battle-aged males by AK-47s gender-based?'101

A feminist critique that all violence (direct and structural) facilitated by the circulation of weapons is gendered and that all weapons transfers have the potential for GBV is indicative of the scale of the challenge facing anti-militarist accounts of weapons control. It is also indicative of the ongoing obstacles facing 'the development of anti-militarist politics of peace' in the Women, Peace and Security (WPS) agenda more widely, ${ }^{102}$ which has itself demonstrated a 'tendency towards militarization'. ${ }^{103}$ The disappearance of historical feminist commitments to

\footnotetext{
${ }^{93} \mathrm{UN}$, The Arms Trade Treaty, Article 7.4.

${ }^{94}$ Clapham et al., The Arms Trade Treaty, p. 277.

${ }^{95}$ Green et al., 'Gender-based violence and the Arms Trade Treaty', p. 553.

${ }^{96}$ Ibid.; da Silva and Wood, 'Article 7: Export and export assessment', p. 128; WILPF.

${ }^{97}$ Caroline Green, Deepayan Basu Ray, Claire Mortimer, and Kate Stone, 'Gender-based violence and the Arms Trade Treaty: Reflections from a campaigning and legal perspective', Gender and Development, 21:3 (2013), p. 558; Ray Acheson and Maria Butler, 'WPS and Arms Trade Treaty', in Sara E. Davies and Jacqui True (eds), The Oxford Handbook of Women, Peace and Security (Oxford: Oxford University Press, forthcoming, 2019).

${ }^{98}$ Cynthia Enloe, Bananas, Beaches and Bases: Making Feminist Sense of International Politics ( ${ }^{\text {nd }}$ edn, Oakland: University of California Press, 2014), p. 23.

${ }^{99}$ WILPF, the IANSA Women's Network, Amnesty International and Religions for Peace, The Arms Trade Treaty: Securing Women's Rights and Gender Equality (June 2012), available at: \{http://www.peacewomen.org/assets/file/PWPublications/WILPF/joint_policy_paper_on_gender_and_the_arms_trade_treatyjunejuly2012.pdf\}. WILPF, Gender Based Violence and the Arms Trade Treaty (2015), available at: \{http://www.reachingcriticalwill.org/images/documents/Publications/GBV_ATT-brief.pdf.

${ }^{100}$ Enloe, Bananas, Beaches and Bases, pp. 24-5.

${ }^{101}$ Paul Kirby (@ProfPCK), Twitter post, 10.07 am, 30 January 2018, available at: \{https://twitter.com/ProfPCK/status/ 958401293462142976\}.

${ }^{102}$ Laura J. Shepherd, 'Making war safe for women? National action plans and the militarisation of the women, peace and security agenda', International Political Science Review, 37:3 (2016), p. 332.

${ }^{103}$ Soumita Basu and Laura J. Shepherd, 'Prevention in pieces: Representing conflict in the Women, Peace and Security agenda', Global Affairs (2018), p. 10, available at: doi: 10.1080/23340460.2017.1415723; also Acheson and Butler, 'WPS and Arms Trade Treaty'.
} 
disarmament in the WPS agenda represents in part a pragmatic choice by campaigners, but also 'exposes the lack of compatibility between the ontologies of feminist peace and the state system'. 104

\section{Diversion and the treatment of ammunition}

A key practice of the illicit trade is diversion, or re-transfer: when weapons do not end up with their stated end-user, or are used for an unauthorised purpose. Ammunition is particularly susceptible to diversion, because of the quantities in which it is transferred. Under a distinct article of the treaty, States Parties are to 'take measures to prevent' diversion, which can include, but does not require, refusing to authorise exports. ${ }^{105}$ Parallel to this is the treatment of ammunition, also treated under its own article rather than being included as a category of equipment in the scope of the treaty. This means that, while the provisions of Articles 6 and 7 apply to ammunition, the article on diversion does not. So while diversion can, technically, be treated as strongly as the other criteria (as the provision is there to refuse a licence on these grounds), politically speaking the precision of the obligation is weaker than other criteria. In earlier drafts of the treaty text, there was no provision for ammunition, in concession to the US. ${ }^{106}$ Other states also objected to the inclusion of ammunition during the negotiations Russia, China, Canada India, Egypt, among others - but it was the US that took the strongest line, making repeated and explicit proposals to exclude it. Amendments to the eventual treaty text were made to mirror US practice as far as possible, and 'were part of the compromises made to get the US to vote for the final UNGA resolution [to adopt the treaty] and to keep Russia, China and other influential states from voting against it'. ${ }^{107}$

The ultimate formulation of diversion was constructed predominantly for the US's benefit, against the backdrop of its war in Afghanistan. The US military transfers ammunition to the Afghan National Forces, knowing that a proportion of it will inevitably be diverted and used against US troops. In 2009, for example, over half of a sample of rifle magazines found on Taliban casualties included bullets or cartridges identical to those provided by the US to Afghan government forces. There is a strong suggestion that ammunition procured by the Pentagon for Afghan forces has been diverted and then used against US troops. ${ }^{108}$ The US accounts for half of the world's medium and large calibre ammunition exports and a quarter of small calibre ammunition exports; it also already controls such transfers under national legislation. ${ }^{109}$ So the issue is the US refusal to have regulation encoded in a multilateral instrument, rather than an unwillingness to regulate at all. The US government pressed for, and won, the exclusion of ammunition from the treaty's scope ${ }^{110}$ and the separate and distinct treatment of diversion. This was despite the position of many African, Latin American, and Caribbean states that the inclusion of ammunition in the scope of the treaty was 'essential' for both state and human security concerns. ${ }^{111}$ US war-fighting - a transnational and asymmetrical practice - and its relationship with a key client was thus central to the negotiation of the treaty. While the US

\footnotetext{
${ }^{104}$ Tickner and True, 'A century of international relations feminism', p. 9.

${ }^{105} \mathrm{UN}$, The Arms Trade Treaty, Article 11.

${ }^{106}$ Kirkham, cited in Bolton and James, 'Nascent spirit of New York or ghost of arms control past?', p. 6.

${ }^{107}$ Edmond E. Seay, 'Article 3: Ammunition/munitions', in da Silva and Wood (eds), Weapons and International Law, pp. $56-8$.

${ }^{108} \mathrm{C}$. J. Chivers, 'Arms sent by US may be falling into Taliban hands', New York Times (19 May 2009), available at: \{http:// www.nytimes.com/2009/05/20/world/asia/20ammo.html?_r=1\&scp=13\&sq=gun\&st=nyt\}.

${ }^{109}$ Neil Corney and Nic Marsh, Aiming for Control: The Need to include Ammunition in the Arms Trade Treaty (Oslo: PRIO, 2013).

${ }^{110}$ Owen Greene, 'Accommodating the major "sceptical" states in the ATT', ATT Monitor (27 July 2012), available at: \{http://attmonitor.blogspot.co.uk/2012/07/accommodating-major-sceptical-states-in.html\}.

${ }^{111}$ Bromley et al., 'The UN Arms Trade Treaty', p. 1044.
} 
claims that this is a treaty about bringing others up to its standards, those very standards are written in a way to facilitate US war-making and foreign policy practices.

\section{Exclusion of domestic procurement and civilian possession}

The examples so far have focused on disagreements; yet there was consensus on a key silence in the treaty as to what is to be regulated. States' military spending, arms production, and domestic procurement are excluded from the remit of the ATT, as is the civilian possession of guns. Superficially, this is unremarkable: the ATT is a multilateral arms trade regulation treaty, focusing on international weapons transfers between states, rather than a disarmament treaty. States' sovereign right to determine their own military needs and govern their own domestic social relations is a strong counter to the development concern over what constitutes appropriate levels of spending or types of gun regulation law, and humanitarian concerns over the use of weaponry. Probing more deeply, however, we see fundamentally political questions at stake, around the role of organised violence in forms of political community and political economy.

Southern states made the loudest calls for the exclusion of domestic procurement: Brazil and other emerging producers insisted on the exclusion of sustainable development as a criterion to be included as part of the national risk assessment, on the grounds that this would intrude on states' right to determine their own spending priorities. Other Southern states challenged asymmetry more directly, with states involved in regional antagonism, such as Pakistan and DPRK, criticising the global military imbalance occasioned by Western military preponderance (in which Western states are able to produce a higher proportion of their own weaponry and are thus less reliant on arms transfers, and also supply weapons to regional allies, friends, and proxies) as the context in which debate about arms transfers takes place. ${ }^{12}$ This Southern emphasis on sovereignty and asymmetry is indicative of the way nation-state militarism is shot through with North-South relations: many Southern states have postcolonial reasons for insisting on nation-state militarism. The bracketing of domestic procurement means that a significant portion of the arms trade is off the multilateral agenda. Yet military production is significantly internationalised, even for those states more able to produce more of their own equipment. ${ }^{113}$ However, international concern remains primarily oriented towards Southern states' practices.

Civilian possession was another US redline, and is the flipside of its position on transfers to non-state actors, as well as a good indicator of civil society militarism. The sacrosanct character of the Second Amendment in mainstream US debate generated ideological hostility from many quarters in the US to the 'egregious provisions' of the ATT that pose a 'pressing international threat to US gun owners. ${ }^{114}$ Pro-control campaigners tried to deflect this pressure by reassuring them the ATT was not about civilian possession, and domestic gun control issues would not be affected by it. ${ }^{115}$ Strategically understandable from the point of view of trying to get the world's largest arms exporter on board with the negotiations, substantively this is a problematic position. Civilian gun markets are off the multilateral agenda because the ATT is about international transfers: but questions about the adequacy of the regulation of the US domestic market are important not only in terms of the racial and gendered politics of domestic gun violence, but also

\footnotetext{
${ }^{112}$ States' statements to the UN during the negotiating process available at: $\{\mathrm{http}: / / \mathrm{www} . u n . o r g /$ disarmament/ATT/\}.

${ }^{113}$ As well as being the world's largest arms exporter, the US is the $12^{\text {th }}$ largest importer, importing from European states such as Germany, the UK and France, and engaged in collaborative arms production with Canada; European states also engage in transnational procurement projects; and the UK relies on imports from the US. SIPRI Factsheet 2017, 'Trends in International Arms Transfers' (2016), available at: \{https://www.sipri.org/sites/default/files/Trends-in-international-armstransfers-2016.pdf\}.

${ }^{114}$ National Rifle Association of America, Institute for Legislative Action, 'International \& United Nations Gun Control' (n.d.), available at: \{https://www.nraila.org/issues/internationalun-gun-control-issues/\}.

${ }^{115}$ Adotei Akwei, 'Fact vs. Fiction: Arms Trade Treaty and Gun Ownership in the US' (6 July 2012), available at: \{www. blog.amnestyusa.org/us/fact-vs-fiction-arms-trade-treaty-and-gun-owernship-in-the-us/\}.
} 
in terms of the regional circulation of weapons and their role in drug wars and organised crime. The US has disproportionately high levels of firearm-related death and injury compared to other industrialised states. ${ }^{116}$ More women were murdered by an intimate partner using a gun in the US between 2001 and 2012 than the total number of US troops killed in action in the entire wars in Iraq and Afghanistan combined. ${ }^{117}$ And gun violence but also gun control are racialised and gendered practices bound up with the very definition of citizenship in ways that are challenging for the gun control movement. ${ }^{118}$ The US civilian gun market also plays a major role in regional gun crises in the Americas. Mexico, for example, has some of the most restrictive gun legislation in the world and was an early ratifier of the Arms Trade Treaty. Yet more than 250,000 guns were purchased in the US and smuggled into Mexico between 2010 and 2012, in part facilitated by lax US regulations. ${ }^{119}$

\section{Conclusion}

The disagreements and silences of the ATT negotiations demonstrate the ways in which weapons circulation and regulation are marked by different forms of militarism. The human security agenda has made significant inroads to international public policy and social science scholarship, and was an explicit driver of the ATT. While there is much in the treaty that optimists see as having the potential to better control the circulation of weapons, the argument put forward in this article is that it is a mistake to see the treaty as a victory for human security over militarism. Rather, human security has chipped away at some of the most egregious manifestations of militarism, been silent on others, and proved to be an accommodation with global militarism in its various forms. Human security, political economy and sovereignty came into contestation during the negotiations as expressions of different modes of militarism.

Weapons circulation takes places within a system: there is a world arms market (including legal and illicit strands) marked by asymmetry, hierarchy, and transnational practices, in which many major exporting states that claim to care about human security, in particular European states, already participate in regimes based on ATT-like principles. Those that don't, or are ambivalent about such multilateralism - in particular Russia and China, and the US, respectively - are sceptical about claims made on the basis of human rights and IHL. Claims to protect human security disconnect human rights and IHL violations from these patterns of military asymmetry and hierarchy, and generate resistance from non-liberal suppliers and recipients. So the human security agenda rests on the assumption that international politics can remain militarised in one way (the absence of efforts at disarmament or tackling military spending or military asymmetry) and yet be demilitarised in another (efforts to decrease the likelihood that weapons will be used in human rights or IHL violations), in ways that the examples discussed above suggest are untenable. Resistance to the ATT from a significant minority of Southern states may well be politically ugly, but needs to be understood in the context of asymmetry in the world

\footnotetext{
${ }^{116}$ UNODC, Global Study on Homicide (2013).

${ }^{117}$ Arkadi Gerney and Chelsea Parsons, Women Under the Gun (Washington, DC: Center for American Progress, 2014), p. 1, available at: $\{\mathrm{http} / / \mathrm{cdn}$.americanprogress.org/wp-content/uploads/2014/06/GunsDomesticViolence2.pdf $\}$. I am grateful to Jacqui True to alerting me to this statistic.

${ }^{118}$ Maxine Burkett, 'Much ado about ... something else: D.C. v. Heller, the racialised mythology of the Second Amendment, and Gun Policy Reform', The Journal of Gender, Race \& Justice, 12 (2009), pp. 57-105; Roxanne Dunbar-Ortiz, Loaded: A Disarming History of the Second Amendment (San Francisco: City Light Books, 2018); Caroline Light, Stand Your Ground: A History of America's Love Affair with Lethal Self-Defense (Boston: Beacon Press, 2017); Eric Primm, Robert M. Regoli, and John D. Hewitt, 'Race, fear and firearms: the roles of demographics and guilt assuagement in the creation of a political partition', Journal of African American Studies, 13:1 (2009), pp. 63-73.

${ }^{119}$ Topher McDougal, David A. Shirk, Robert Muggah, and John H. Patterson, 'The Way of the Gun: Estimating Firearms Traffic Across the US-Mexico Border', Igarapé Institute, University of San Diego Trans-Border Institute (March 2013), available at: $\{\mathrm{http} / / /$ catcher.sandiego.edu/items/peacestudies/way_of_the_gun.pdf\}.
} 
military order, as does US dominance of the negotiations for a treaty to which it is a signatory but not a State Party.

In the desire to promote the spread of human security practices, there has been little attention to why an initiative such as the ATT might be resisted, beyond narrowly strategic or instrumental concerns or a failure to internalise human security norms. Thinking about modes of militarism, and the ways in which the human security agenda has transformed, but not necessarily diminished, militarism can help us think more creatively, both analytically and politically, about what is at stake. We need to understand and explain patterns of militarism because of the paradoxical role of military power and systematic or organised violence in international relations. On the one hand, military power has historically been fundamental to the constitution of organised political power, be it in the form of the state or otherwise. On the other hand, demilitarisation from current levels and forms is a condition for improved human security. A contraction of the influence of the "social relations, institutions and values" of war and war preparation on social relations, institutions and values more generally ${ }^{120}$ reduces the likelihood of violent responses to political problems, reduces the secrecy and corruption associated with military decisions or military involvement in the economy, and lowers the opportunity costs associated with high levels of military spending, to name a few reasons. But militarism has been pushed off the agenda, precisely because it strikes at the core issues around war preparation and the constitution of political community and political economy, and because the maintenance of coercive capacities in the South is central to aid donors' and Southern elites' interests, not to mention the entrenched coercive orientation of Northern states' foreign policies.

For these reasons a human security agenda is limited in terms of its ability to generate more restrictive weapons transfer practices. However, it is also deeply interested, in the sense of having political effects. Human security has become a dominant policy orientation among aid donors and NGOs, is eminently fundable by donors who claim the mantle of benevolence without wanting to change their weapons transfer practices, and has been mobilised in scholarship in pursuit of a normative project. While the practical gains made by any treaty will always be partial, the more significant ramification is that the gains made in the ATT help set the parameters of politically feasible action, and obscure some of the core political projects that are sustained by the circulation of weapons.

Acknowledgements. I presented the first version of what eventually became this article to my Sussex colleagues at our Research in Progress seminar. For specific comments and advice then and since, I am grateful to Jan Selby, Beate Jahn, Kamran Matin, Patricia Owens, and Rorden Wilkinson. Thanks also to Jacqui True and to the anonymous reviewers for their careful comments.

Anna Stavrianakis is Senior Lecturer in International Relations at the University of Sussex. Her main areas of research are the international arms trade, militarism, and critical military, security, and war studies. Most recently, she is the co-editor, with Maria Stern, of the special issue on 'Militarism and Security: Dialogue, Possibilities and Limits', in Security Dialogue, 49:1-2 (2018).

\footnotetext{
${ }^{120}$ On Shaw's definition of demilitarisation, see Martin Shaw, War and Genocide: Organized Killing in Modern Society (Cambridge: Cambridge, 2003), p. 106.
}

Cite this article: Stavrianakis, A. 2018. Controlling weapons circulation in a postcolonial militarised world. Review of International Studies 45: 57-76. doi:10.1017/S0260210518000190 